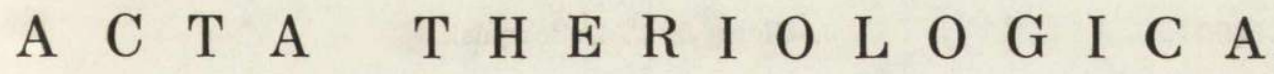 \\ VOL. XVII, 30: 399-406. \\ BIAEOWIEŻA \\ October, 1972
}

Jan G IENC \& Teresa D OBOSZYŃSKA

\section{Macromorphological Description of the Genital Organs of the Female Beaver}

[With 2 Tables \& 9 Figs]

\begin{abstract}
A description is given of organa genitalia feminina of the beaver, Castor fiber $\mathrm{L}$. It was found that cervix uteri has two canales cervicis and the other paired parts of the uterus are not differentiated into corpus and cornua. The long vagina runs to the rear into a strongly developed vestibulum vaginae, opening together with the rectum into pseudocloaca. Vestibulum vaginae has the large diverticula lateralia vestibuli vaginae characteristic of this species, termed praeputial "glands", in which castoreum is secreted.
\end{abstract}

\section{INTRODUCTION, MATERIAL AND METHODS}

In view of the lack of exhaustive morphological elaborations of the anatomy of the beaver, Castor fiber Linnaeus, 1758, macromorphological observations were made of the female genital organs on material obtained from animals kept in captivity in the Institute of Genetics and Animal Breeding at Popielno and the Fur Farm at Wiartel.

The material used for this study consisted of dead animals only, numbering 9 adult females and 6 females a few days old. Observations were made on both fresh material and material fixed in $3 \%$ formalin, employing the anatomical preparation method and also preparation using a magnifying glass. Results were documented with photographs and drawings.

\section{RESULTS}

Both the right and left ovaries are situated in the immediate vicinity of extremitas caudalis renis, at the level of the fourth lumbar vertebra (Fig. $1-1$ and Fig. $6-1$ ). The ovary is suspended by the mesovarium, which descends from the dorsal wall of the abdominal cavity near the diaphragm and occupies a position lateral to the kidney. The ovaries, 
which are oval in shape (Fig. $2-1)^{1}$, are clearly visible in fresh preparations on account of their light colour (Fig. $6-1$ ). Dimensions and weight of the ovaries are given in Table 1. The long axis of the ovary usually lies in planum paramedianum. Margo liber and facies medialis of the ovary are clearly visible in situ (Fig. 2). Margo mesovaricus and extremitas tubaria and extremitas uterina can be easily distinguished on the ovary. Extremitas uterina is connected with the uterus by a short, strong ligamentum ovarii proprium, while facies lateralis is turned towards the bursa ovarica, which is well developed in the beaver (Fig. $2-2$ ). The position of the ovaries is similar in both newborn and completely mature females.

Table 1

Dimensions (in $\mathrm{mm}$ ) and weight (in $\mathrm{mg}$ ) of the beaver ovaries.

\begin{tabular}{|c|c|c|c|c|c|c|c|c|c|}
\hline $\begin{array}{l}\text { No of } \\
\text { animal }\end{array}$ & $\begin{array}{l}\text { Age } \\
\text { months }\end{array}$ & lenght & $\begin{array}{l}\text { Right } \\
\text { width }\end{array}$ & $\begin{array}{l}\text { ovary } \\
\text { height }\end{array}$ & weight & lenght & $\begin{array}{r}\text { Left } \\
\text { width }\end{array}$ & $\begin{array}{l}\text { ovary } \\
\text { height }\end{array}$ & weigth \\
\hline 1 & 23 & 22 & 11 & 4 & 640 & 23 & 7 & 5 & 670 \\
\hline $2^{*}$ & 69 & 21 & 9 & 5 & 750 & 21 & 14 & 5 & 790 \\
\hline $3^{*}$ & 96 & 27 & 16 & 8 & 800 & 29 & 17 & 9 & 850 \\
\hline 4 & 60 & 17 & 13 & 7 & 780 & 21 & 12 & 7 & 780 \\
\hline 5 & 66 & 22 & 12 & 5 & 750 & 22 & 14 & 6 & 730 \\
\hline $6^{*}$ & 72 & 24 & 14 & 6 & 790 & 26 & 13 & 7 & 790 \\
\hline 7 & 108 & 22 & 9 & 4 & 710 & 24 & 9 & 5 & 710 \\
\hline 8 & 24 & 17 & 3 & 2 & 250 & 19 & 5 & 3 & 135 \\
\hline $9^{*}$ & 60 & 22 & 8 & 7 & 780 & 18 & 7 & 6 & 730 \\
\hline
\end{tabular}

Tuba uterina is relatively short (see Table 2). Infundibulum tubae uterine does not possess its typical fimbriae tubae (Fig. 3-1). Ampulla tubae uterinae is characterized by a slightly spiral course (Fig. $3-2$ ). There is a double $S$-bend the oviduct immediately behind isthmus tubae uterinae (Fig. $3-3$ ). Pars uterina runs parallel to the uterus, then bends sharply and running in the direction of the ovary thrusts between perimetrium and myometrium for a space of about $5 \mathrm{~mm}$ and ends in the form of ostium uterinum tubae about $3 \mathrm{~mm}$ from the cranial end of the uterus.

In the beaver the uterus has a duplex cavum uteri and is characterized by the general appearance typical of this species. The long cervix uteri gives the impression of a corpus and the other paired parts of the uterus are similar in appearance to cornua uteri, so that the uterus as a whole is shaped like a letter Y. Cervix uteri is situated between the rectum and vesica urinaria. The paired parts of the uterus, as from cervix uteri,

${ }^{1}$ Figs. 1, 2, 3, 5 see Plate I, figs. 6-9 see Plate II. 
bend caudal and laterad, after which they bend again in a dorsal direction and next take the position similar to that of cornua uteri in, for instance, bitches.

Cervix uteri (Fig. 1 -5) in adult females is about $50 \mathrm{~mm}$ long and has a tunica muscularis, far thicker than that of the other paired parts of the uterus, which surrounds the two canales cervicales uteri. Each canalis cervicis uteri is bounded by tunica mucosa with strong plicae longitudinales. Portio vaginalis cervicis extends in the form of a plug into the lumen of the vagina (Fig. $4-5$ ) and has two slit-like ostia uteri externa, which are separated by a distinct crest. The paired parts

Table 2

The lenght of the oviducts, uterus and vagina of the beaver (in $\mathrm{mm}$ ).

\begin{tabular}{lccccc}
\hline \multirow{2}{*}{$\begin{array}{l}\text { No of } \\
\text { animal }\end{array}$} & \multicolumn{2}{c}{ Oviduct } & \multicolumn{2}{c}{ Uterus } & \\
& Right & Left & Right & Left & Vagina \\
\hline & & & & & \\
\hline & 84 & 86 & 222 & 226 & 145 \\
3 & 89 & 64 & 218 & 218 & 155 \\
4 & 84 & 83 & 284 & 278 & 170 \\
5 & 97 & 99 & 240 & 219 & 135 \\
6 & 82 & 83 & 214 & 216 & 136 \\
7 & 88 & 89 & 239 & 244 & 145 \\
8 & 82 & 83 & 222 & 219 & 136 \\
9 & 35 & 30 & 145 & 140 & 135 \\
& 82 & 83 & 242 & 214 & 136 \\
\hline
\end{tabular}

of the uterus, which, in an adult female, are about $150 \mathrm{~mm}$ long and $10 \mathrm{~mm}$ in diameter, are suspended by a strongly developed mesometrium which cranial passes into mesosalpinx, and caudal into tunica serosa cervicis uteri. Lateral the mesometrium passes into a very well developed ligamentum teres ( $s$. chorda uteri) which through anulus inguinalis profundus enters canalis inguinalis (Fig. 5 - 8). A.a. ovaricae (dextra et sinistra) run into ligamentum latum uteri, and each of them supplies an ovary and tuba uterina and, as ramus tubarius, almost the whole paired part of the uterus (Fig. $6-4$ ). The remaining paracervical part of this part of the uterus is supplied by numerous branches running from a. ilica externa, corresponding to a. uterina. The vagina is similar in shape to a long tube (Fig. $4-6$ ), and in an adult female is about $145 \mathrm{~mm}$ long and $20 \mathrm{~mm}$ in diameter. As the vagina passes into cervix uteri it forms fornix vaginae dorsalis. Tunica mucosa vaginae forms rugae vaginales (Fig. $7-5$ ). Tunica muscularis vaginae is well developed and is separated from the rectum on the dorsal side by septum 
recto-vaginale of connective tissue, and on ventral side from urethra feminina by septum urethro-vaginale. About two-thirds of the vagina lies within cavum pelvis, and the remaining part in regio postpelvicalis (Fig. 4).

Vestibulum vaginae (Fig. $4-7$ ) in the beaver has a fairly complex and characteristic structure and constitutes the part of the genital tract which connects the vagina with a diverticulum of skin (Fig. $4-13$ ) termed by some authors, probably incorrectly, the cloaca. Diverticulum urethrale vestibuli vaginae, which is fairly large in the beaver, starts on the ventral side on the boundary between vestibulum vaginae and the vagina. Diverticulum urethrale vestibuli vaginae is funnel-shaped (Fig. $4-2$ and Fig. $7-3$ ) and is lined by a relatively thin tunica mucosa. The widened part of the funnel runs to vestibulum vaginae and the narrowed part surrounds ostium urethrae externum (Fig. $7-4$ ).

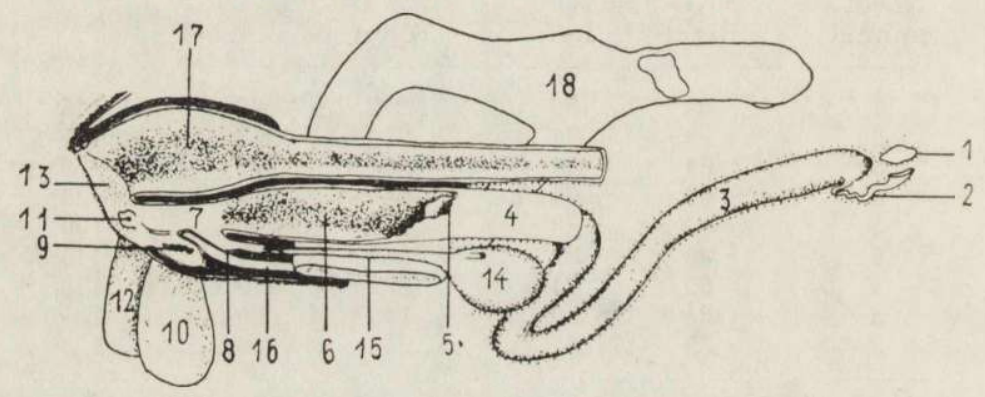

Fig. 4. Schematic representation of the female genital system.

1 - ovarium, 2 - tuba uterina, 3 - uterus, 4 - cervix uteri, 5 - portio vaginalis cervicis, 6 - vagina, 7 - vestibulum vaginae, 8 - diverticulum urethrale vestibuli vaginae, 9 - ostium diverticuli lateralis vestibuli vaginae, 10 - diverticulum laterale vestibuli vaginae, 11 - ostium sacci analis, 12 - saccus analis, 13 - pseudocloaca, 14 - vesica urinaria, 15 - urethra feminina, 16 - clitoris, 17 - rectum, 18 - pelvis.

The clitoris is strongly developed in the beaver, being about $70 \mathrm{~mm}$ long (Fig. 4-16 and Fig. 8). Crura clitoridis, starting from arcus ischiadicus, in connecting form a long (about $50 \mathrm{~mm}$ ) corpus clitoridis passing caudad into glans clitoridis, which protrudes into vestibulum vaginae (Fig. $8-1$ ). The latter is particularly capacious from below glans clitoridis, extending sidewards and forming a large diverticulum laterale vestibuli vaginae on each side (Fig. $4-10$ and Fig. 5 - 4), described as the preputial "gland «. Vestibulum vaginae is connected by large slit-like openings with the above-mentioned diverticula (Fig. 4-9 and Fig. 8-6). To the rear vestibulum vaginae runs to the cutaneous 
diverticulum (Fig. $4-13$ ) together with the rectum and on this account this diverticulum is also termed the cloaca or, which appears more correct to us, the pseudocloaca. The anal and urogenital ostia opening into the pseudocloaca are separated by plica transversa mucosae (Fig. $9-2$ ). On the lateral walls of the urogenital ostium, that is, at the level of the boundary line separating pseudocloaca from vestibulum vaginae, sacci anales (Fig. $4-12$ and Fig. 5-5) start on the characteristic papillae (Fig. $4-11$ ) and are similar in shape to diverticula lateralia vestibuli vaginae, although they are distinctly smaller and situated more caudad, and also softer to the touch. The pseudocloaca, lined with hairless skin, is characterized by grey pigmentation and numerous small folds. The external opening of the pseudocloaca is situated, depending on the animal's size, from a few to several centimetres from arcus ischiadicus and is easy to observe on account of the absence of hair in the immediate vicinity of this opening. The caudal parts of rectum and vagina and also vestibulum vaginae, sacci anales and the pseudocloaca are included in the composition of regio postpelvicalis, which is of considerable dimensions in the beaver.

\section{DISCUSSION}

Our observations regarding the external appearance of te ovaries agree with the data given by Provost (1962), and show that they are almost smooth, as the developing Graafian follicles protrude only slightly above the surface of the ovary. Our observations, like Provos t's (1962), show that the ovaries are distinctly larger and heavier in pregnant females. According to Provost (1962) corpora lutea, of a cream or dark yellow colour, are very distinct in ovaries fixed in $A F A$ fluid, but corpora lutea were very faintly visible in the ovaries we fixed in formalin. Unlike nutria in which, as S le bodziński $(1957,1959)$ states, bursa ovarica does not occur, in the beaver it is well developed and surrounds a considerable part of the ovary. The part of the oviduct lying immediately behind isthmus tubae uterinae forms an $S$-shaped bend similar to that described by Slebodziński (1959) in the nutria. We encountered a variety of terms in descriptions of uterus duplex in the nutria; for instance $\mathrm{Koch}(1953)$ and S lebodziński $(1957,1959)$ term the extracervical parts of the uterus the corpus, and L u tnicki (1958) the cornua. Hinze (1950) states that uterus duplex in the beaver has long and narrow cornua. Ž ed e nov (1965) distinguishes uterus duplex with one or two ostia. The uterus with a single ostium opens, according to this author, into the vagina with one common ostium and occurs, inter alia, in the beaver, while uterus duplex with 
two ostia is characterized by the presence of a double cervix uteri and opens into the vagina in two independent ostia and, as shown by the data given by Č erveny (1960) and Ž e denov (1957), uterus duplex in the rabbit may comply with these criteria.

Our observations show that in the beaver the single cervix uteri opens into the vagina not in one common, but in two ostia, and the relations found in the structure of portio vaginalis cervicis uteri are similar to those described in nutria by Koch (1953), S le bodziński $(1957,1959)$ and Lutnicki (1958). In respect of arterial supply to the uterus in the beaver our observations agree with the data given by Andrejeva (1950).

Many authors have dealt in detail with the problem of the so-called preputial glands in the beaver. Hinze (1953), who describes organa genitalia feminina in the beaver in one sentence only, gives a very exhaustive description of the preputial glands, defining them as glands with high secreting capacity. On the other hand, according to $\mathrm{Kacni}$ elson \& Orlova $(1954,1956)$, it is incorrect to define these glands as preputial glands since, as shown by these authors' studies, they do not produce any secretion and the castoreum with which they are filled is formed as the result of physical and chemical metabolism and maceration of keratotic and desquamated epithelia by urine, which is resorbed by the capillary system created by concretions of these epithelia. On our part we consider that both development and anatomical relations of these formations permit of defining them as diverticula lateralia vestibuli vaginae.

An interesting problem is presented by regio postpelvicalis occurring in the beaver, and also pseudocloaca, into which the common anal and urogenital ostium opens in females, and the anal and preputial ostium in males. Nikulin (1954) considers that both regio postpelvicalis and pseudocloaca in the beaver are very similar to the relations occurring in Marsupialia and in view of this is disposed to consider the pseudocloaca as the residuum of the cloaca and not as the result of secondary adaptation to a water habitat.

\section{REFERENCES}

1. Andrejeva E. G., 1950: Krovenosnaja sistema rečnogo bobra. Tr. Voronež. Gos. Zap., 5: 77-91.

2. Cerven y C., 1960: Prispevek $\mathrm{k}$ anatomii pohlavnino ustroji samicino kralika (Oryctolagus cuniculus Gray). Sb. Vys. Sk. Zemed., 8, 3: 399-409. Brno.

3. Hinze H., 1950: Der Biber. Akademische Verlag: 1-214. Berlin.

4. Kacnielson Z. S. \& Orlova I. I., 1954: Gistologičeskoe stroene tak nazyvajemyh prepucjalnyh (muskusnyh) želez vzroslogo rečnogo bobra. Tr. Voronež. Gos. Zap. 5: 58-63. 
5. Kacnielson Z. S. \& Orlova I. I., 1956: Razvitie prepucjalnyh želez bobra. Ib. $6: 67-72$.

6. Koch T., 1953: Beitrage zur Anatomie des Sumpfbibers. S. Hirzel Verlag: 85-87. Leipzig.

7. Lutnicki W., 1958: Anatomie und Histologie der Geschlechtsorgane des Sumpfbibers. Annls Univ. Mariae Curie-Skłodowska, DD, 13: 1-25.

8. Nikulin V. N., 1954: Pozaditazovaja oblast' rečnogo bobra. Tr. Voronež. Gos. Zap., 5: 56-58.

9. Provost E. E., 1962: Morphological characteristics of the beaver. J. Wildl. Mgmt., 26, 3: 272-278.

10. Slebodziński A., 1957: Uwagi na temat właściwości budowy anatomicznej żeńskiego układu rozrodczego samicy nutrii (Myocastor coypus Mol.). Med. Wet., 5: $275-278$.

11. Slebodziński E. E. \& Ptak W., 1959: Zarys budowy anatomicznej narządu rodnego samicy nutrii (Myocastor coypus Mol.)., Prz. zool., 1: 31-44.

12. Z edenov V. N., 1957: Anatomija krolika. Sovietskaja nauka: 157-173. Moskva.

13. Ž e denov V. N., 1965: Anatomija damašnih životnyh. Vysšaja Škoła: 365-405. Moskva.

Accepted, Juni 19, 1972.

College of Agriculture,

Institute of Fundamental Veterinary Sciences,

Olsztyn 5, Poland.

\section{Jan GIENC i Teresa DOBOSZYŃSKA}

\section{CHARAKTERYSTYKA MAKROMORFOLOGICZNA UKEADU ROZRODCZEGO SAMICZEGO BOBRA}

\section{Streszczenie}

Przebadano układ rozrodezy samiczy bobra na 9 dorosłych i 6 kilkudniowych samicach. Obserwacje prowadzono na materiale świeżym oraz konserwowanym w formalinie. Jajniki ułożone są na wysokości czwartego kręgu lędźwiowego i mają owalny kształt oraz jasne zabarwienie. Krawędź wolna i powierzchnia przyśrodkowa jajnika są in situ dobrze widoczne. Lejek jajowodu nie posiada typowych strzępów jajowodowych. Bańka jajowodu charakteryzuje się krętym przebiegiem. Bezpośrednio za cieśnią jajowodu występuje podwójne esowate zgięcie jajowodu. Macica podwójna (uterus duplex) składa się z nieparzystej szyjki macicznej i z odcinków parzystych nie zróżnicowanych na trzon i rogi. Szyjka posiada dwa kanały szyjkowe prowadzące do dwu jam macicznych. Długa pochwa przechodzi ku tyłowi w silnie rozwinięty przedsionek pochwy, który wraz z jelitem prostym uchodzi do zachyłka skórnego (pseudocloaca). Przedsionek pochwy wytwarza charakterystyczne dla tego gatunku uchyłki boczne zwane „gruczolami" napletkowymi, w których wytwarza się strój bobrowy (castoreum). 


\section{EXPLANATION OF PLATES}

Plate I.

Fig. 1. General aspect and topography of the uterus of a several days' female. 1 - ovarium, 2 - mesovarium, 3 - tuba uterina, 4 - uterus, 5 - cervix uteri, 6 - ren, 7 - rectum, 8 - vesica urinaria.

Fig. 2. Left ovary.

1 - facies medialis, 2 - bursa ovarica, 3 - uterus.

Fig. 3. Left oviduct.

1 - ostium abdominale tubae uterinae, 2 - ampulla tubae uterinae, 3 - isthmus tubae uterinae, 4 - uterus.

Fig. 5. Female genital organs of the pregnant female, ventral aspect. In the left uterus the regularly developing embryos, in the right - the resorbed embryos. 1 - uterus, 2 - vagina, 3 - vestibulum vaginae, 4 - diverticulum laterale vestibuli vaginae, 5 - saccus analis, 6 - vesica urinaria, 7 - urethra feminina, 8 ligamentum teres uteri.

Plate II.

Fig. 6. The ovaries and uterus of an adult female.

1 - ovarium, 2 - uterus, 3 - aorta abdominalis, 4 - arteria ovarica, 5 - vesica urinaria.

Fig. 7. The vagina and the uretral recess (sagittal section) dorsal view.

1 - glans clitoridis, 2 - vestibulum vaginae, 3 - diverticulum urethrale vestibuli vaginae, 4 - ostium urethrae exterum, 5 - vagina.

Fig. 8. Clitoris, ventral aspect. In order to show the glans clitoridis and openings of the lateral recesses of the vestibule there was made sagittal section of the ventral wall of the vestibul.

1 - glans clitoridis, 2 - corpus clitoridis, 3 - crura clitoridis, 4 - urethra feminina, 5 - vagina, 6 - ostium diverticuli lateralis vestibuli vaginae.

Fig 9. Cutaneous recess.

1 - anus, 2 - plica transversa, 3 - vestibulum vaginae. 


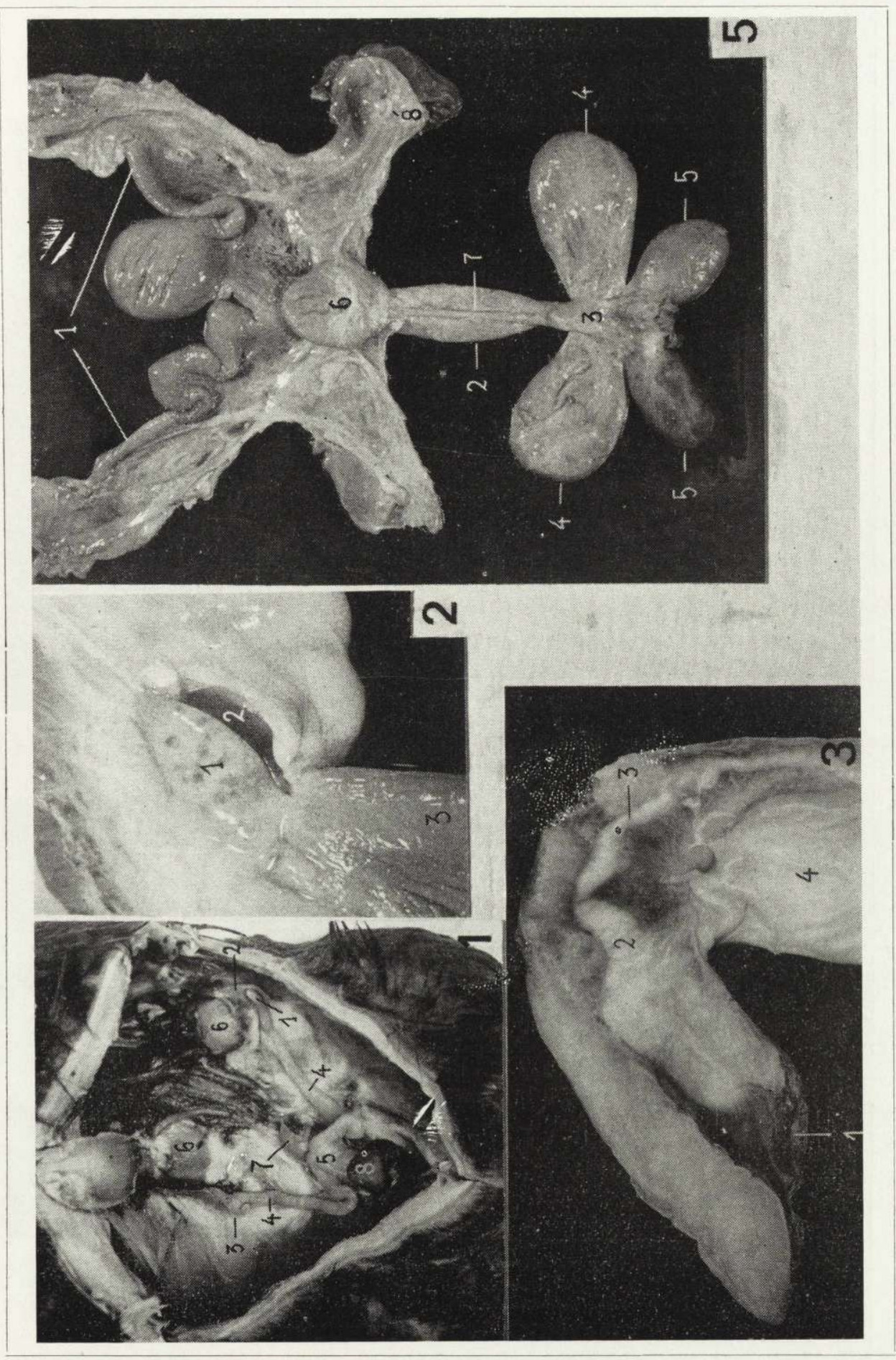

J. Gienc \& T. Doboszyńska

C. Nagięć (1, 3), R. Jaromiński $(5,2)$ phot. 


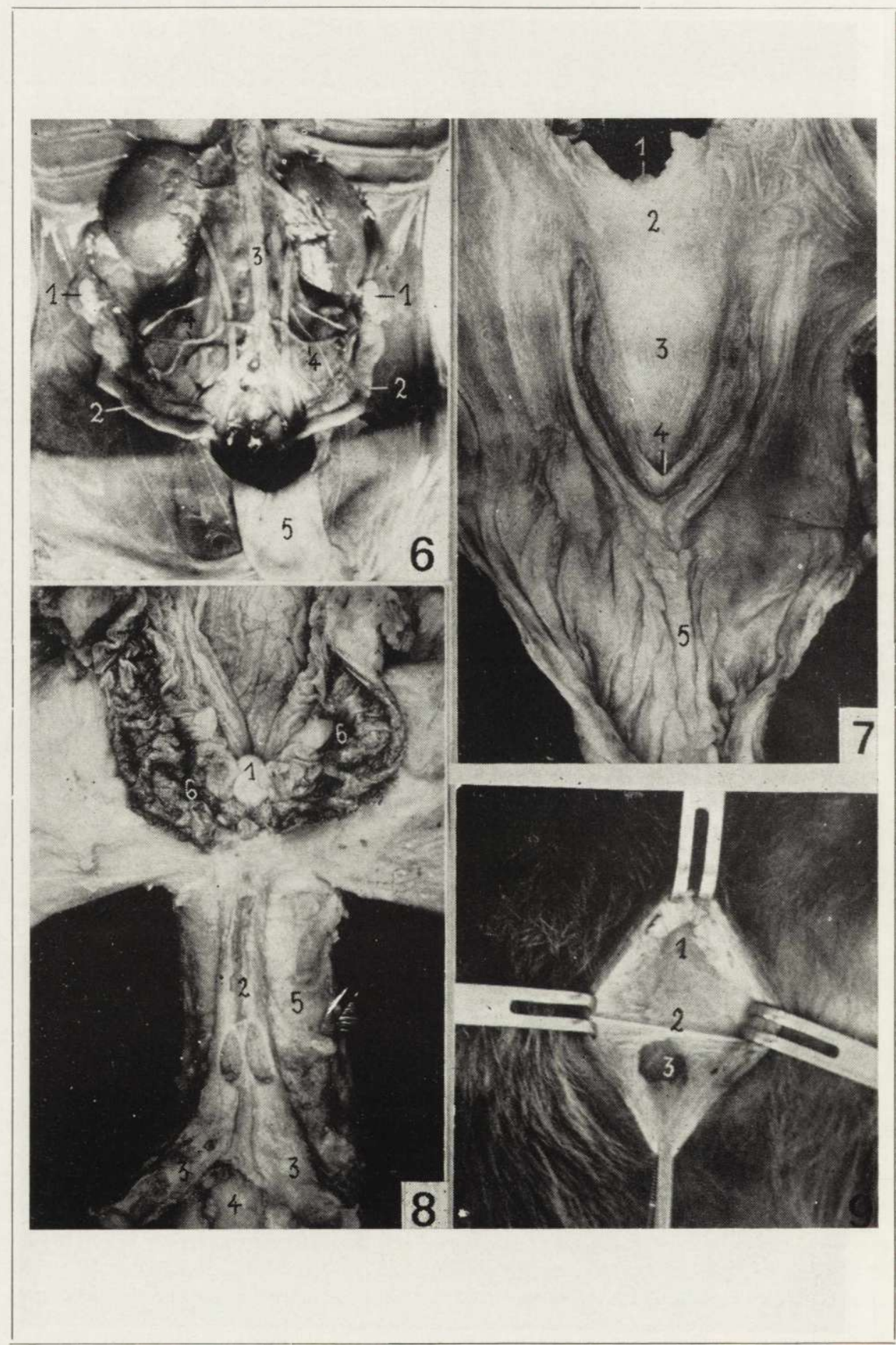

J. Gienc \& T. Doboszyńska

C. Nagięć phot 